\title{
How is coronavirus affecting agriculture in California?
}

\author{
An interview with UC Cooperative Extension experts about the effect of the coronavirus pandemic \\ on food production.
}

Online: https://doi.org/10.3733/ca.2020a0018

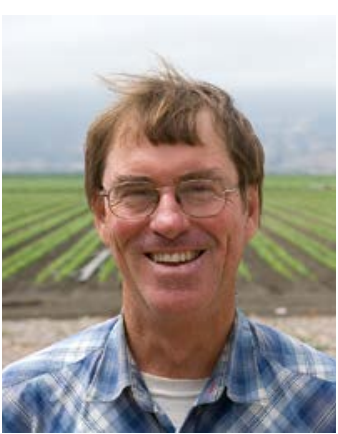

Richard Smith, UCCE Farm Advisor, Monterey County

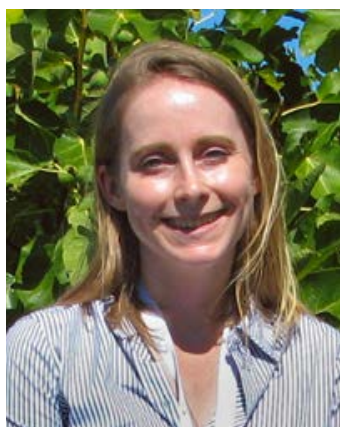

Phoebe Gordon, UCCE Farm Advisor, Madera County

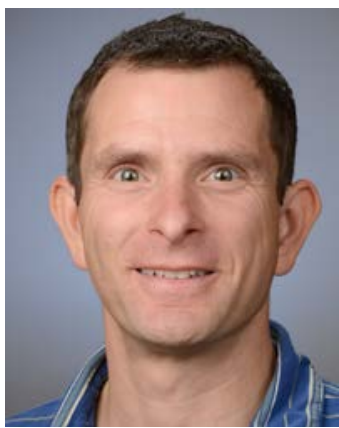

Maurice Pitesky, UCCE Assistant Specialist, UC Davis

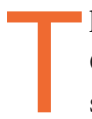
he coronavirus pandemic has affected every Californian and seems likely to continue doing so for some time. But how is COVID-19 affecting the systems that put food on California's tables - and the world's? For insights into the pandemic's effect on food production, we spoke with UC Cooperative Extension (UCCE) experts in three parts of the state: Richard Smith, UCCE Farm Advisor in Monterey County who specializes in vegetable crop production; Phoebe Gordon, UCCE Farm Advisor in Madera County who specializes in orchard crops; and Maurice Pitesky, UCCE Assistant Specialist at UC Davis who specializes in poultry health and food safety.

\section{How is the coronavirus affecting growers and processors and the overall food system in your area of focus now?}

Smith: The vegetable industry here has a couple of components - the retail market to markets such as Walmart, Costco, Safeway and so on, and food service, which is the market selling to restaurants, hotels, schools and institutions. The food service market basically greatly contracted, and growers heavily into food service have been greatly affected. Some may be trying to modify their operations so they can sell to retail, but there are a lot of obstacles - packaging, for example.

Another aspect is labor, and that's a big, evolving issue. I think growers are trying to adjust as best they can. In the field, I see they are spreading people out for social distancing. But workers might live in more dense living quarters, and that's not in the growers' control, and they also do a lot of carpooling. In California processing, so far we don't have the kinds of issues that the meatpacking plants back east have - just mindboggling problems, with thousands of people ill and plants shut down for weeks.

Gordon: For field work, [the level of disruption caused by coronavirus] really depends on what you're doing. If you're looking at irrigation, it tends to be one person, so that's very easily done alone. With pesticides, only a few people are involved so that you won't need to use so much personal protective equipment, which has been hard to source in some cases. But for planting, and for training young orchards, I'm sure they're trying to keep people apart. But it may be hard to do some tasks with just one person, or with people spaced apart, like hand-planting trees. I think things might be tougher when it gets to harvest, especially for something like figs. The picking can be spaced out, but some growers field-pack figs, and then everyone works under one big canopy.

Pitesky: There are two big areas where coronavirus seems to be having an effect. First, we're getting a lot more interest in backyard poultry. That creates some interesting challenges. Some people might eventually realize they don't want the birds and abandon them. And if poor husbandry and biosecurity practices are used, diseases like virulent Newcastle disease can spread from backyards into commercial operations.

The second problem is the challenges in poultry plants and meatpacking plants in general. If processing lines are slowed due to lack of healthy employees or social distancing, everything upstream bottlenecks, which results in less product available commercially and even euthanasia of flocks. Broiler production nationally is down about $15 \%$ right now, reflecting those realities. From a worker safety perspective, meat processing plants are designed to reduce foodborne pathogens and facilitate efficient production. However, the aerosols generated from saws, HVAC systems and cool refrigerator temperatures, which are conducive to optimizing food safety, facilitate the transmission of respiratory pathogens like the coronavirus.

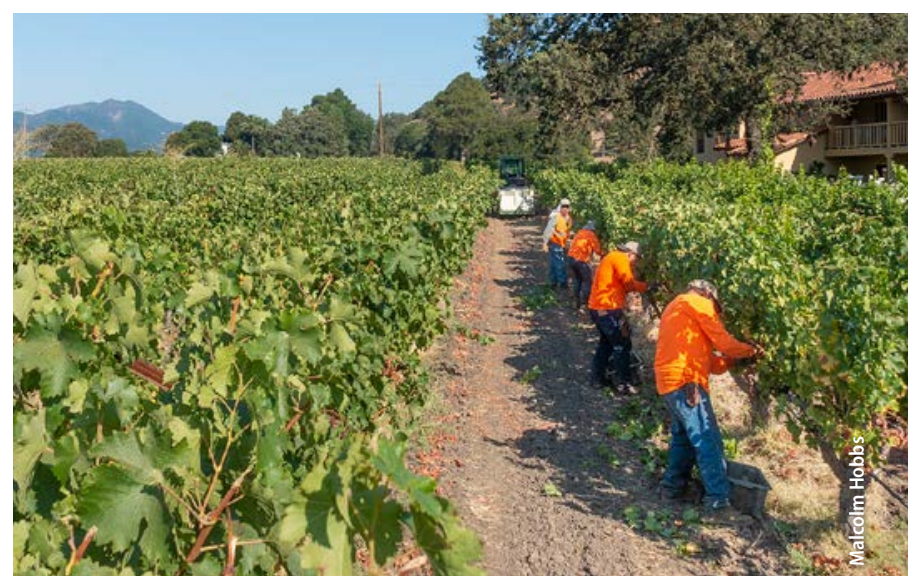

Workers harvesting grapes in California. On some farms, growers are spreading workers out for social distancing. 


\section{How do you expect things to change in the next few months?}

Smith: For growers, there's a lot of uncertainty. Growers who have been at this for a while have their buyers and they know how much to plant each week. But with coronavirus, how do you plant for two months from now? One thing we do know is that people need to eat. But there's also been disruption in the marketing chain. You hear about the problems facing stockers at the grocery, but people in the distribution centers can also get sick. The good thing in California is we seem to be very organized in our response - but people are going to be people. They want to get out of their houses and that does not bode well for containment of the virus. How that will affect agriculture? We don't know.

Gordon: Labor could be a problem. It has been hard to get labor in general, particularly skilled labor. Pruning takes skill, operating machinery takes skill. If farmworkers start getting sick, it's going to make labor issues even harder. But in my area, most things dry and store well. Even figs, you can let them drop from the tree and sell them dried. But in fig and almond harvest, workers tend to work somewhat close depending on the task, and the harvest happens over a short time. The longer you leave nuts on the ground, or the longer you leave them on trees, the greater the chances they'll get infested with insects. So growers face the possibility of crop losses due to labor shortages. If you only have a certain number of people trained to use a shaker, and they get sick, what are you going to do? You can train someone else to use a shaker, but an unskilled person can damage trees to the point where they'll die.

Pitesky: Paid sick leave is going to be a huge issue for processing plants. The working culture in most places is that you work sick, in part because of the lack of paid sick leave. We need to view paid sick leave as a public health shield instead of an employee perk. Infrared temperature guns are needed for screening. Finally,

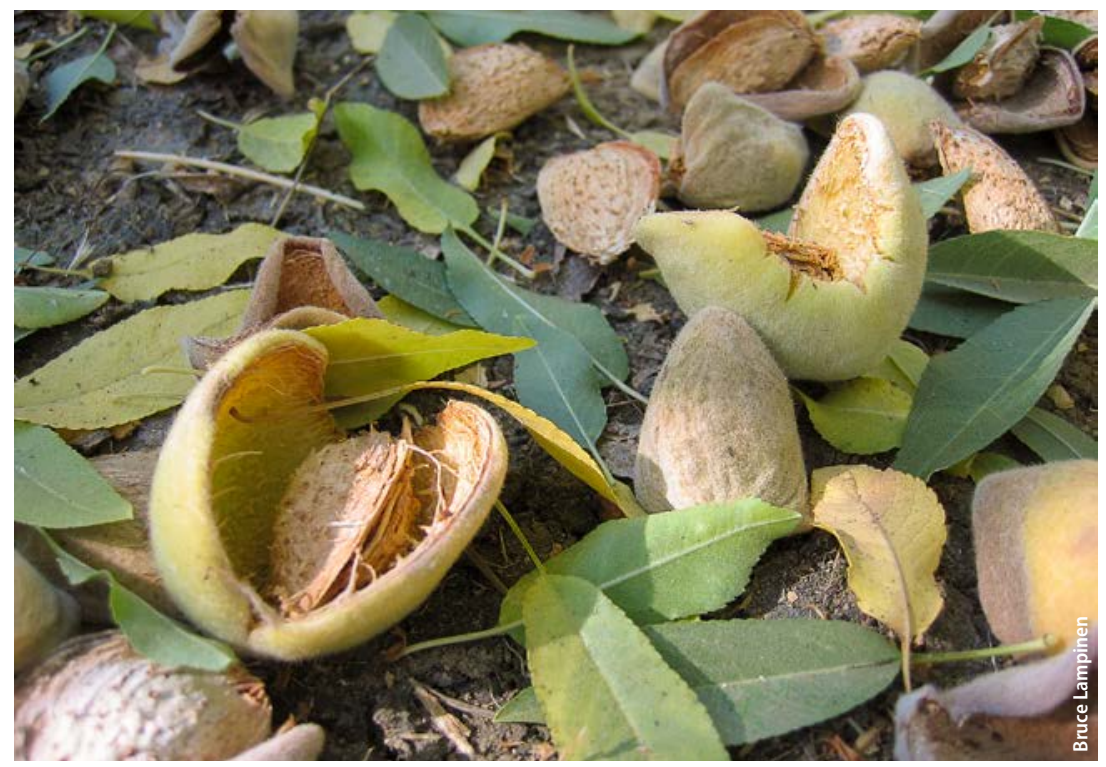

Broilers on a farm in Texas. If processing lines are slowed due to a lack of healthy employees or social distancing, everything upstream bottlenecks, which results in less product available commercially and even euthanasia of flocks.

Almonds ready for harvest. The longer nuts are left on the ground or on trees, the greater the chances they'll get infested with insects.

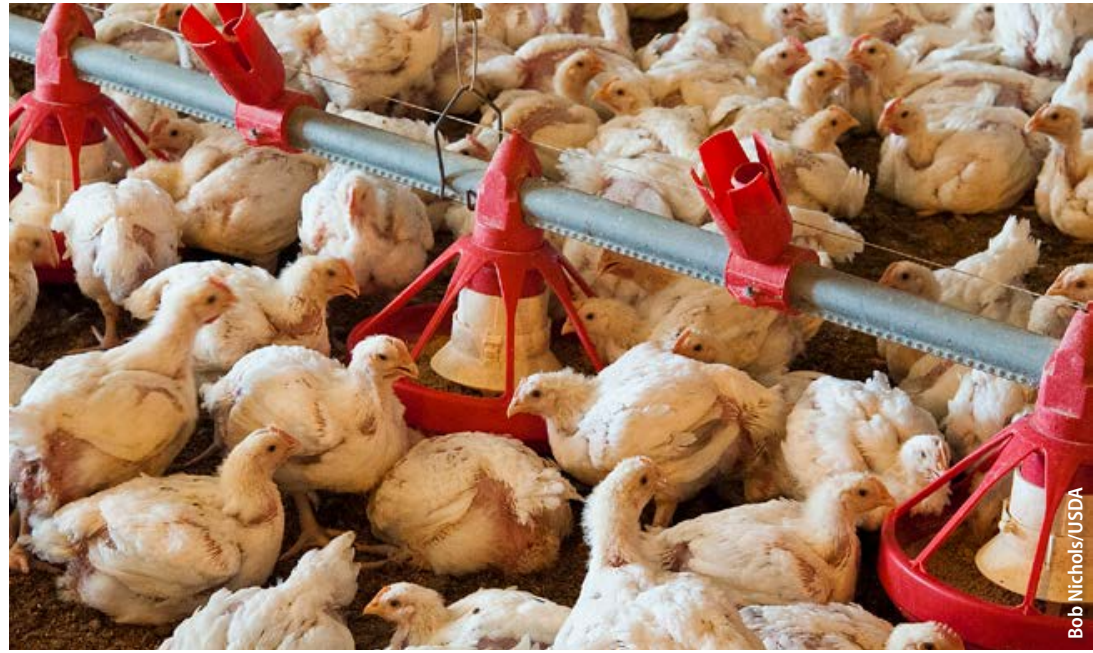

testing for virus and antibodies is a big issue. The presence of antibodies due to natural exposure is not definitively shown to prevent disease or reinfection, but if companies can identify workers who have antibodies after natural exposure, these workers may be extremely useful in order to maintain our meat supply. An additional complication is that undocumented workers may be unlikely to know about or utilize resources with respect to testing or antibody testing.

We're a huge exporter of poultry meat - we're the world's largest exporter of broilers, for example - but the export market may soften. Therefore, any slackening in the export market could be redirected domestically to account for any shortages. It's different on the egg side due to shelf-life issues. You can turn eggs into egg powder, for example. But we don't have a ton of capacity in that area to shift production, and the economics of egg powder are not good for farmers.

\section{What are some ways in which this crisis could result in permanent changes to the food system?}

Smith: Good question. I don't know that much will change in the field. There might be changes in distribution, and consumer preferences and so forth.

Gordon: One possibility is that growers may try to become less reliant on human labor where they can, which has already been happening in ag in general. One reason California orchard crops are dominated by nut crops is that nut crops are already pretty mechanized, while the cost of picking fruit is very high because labor is so expensive.

Pitesky: One possibility is to have more and more automation in poultry. There's a lot already, but there is potential for more, and the realities of what is happening in the meat industry with the spread of COVID will speed this type of innovation. For example, when you walk into some milk plants, it's hard to find people in those places. It's moving in that direction in swine and beef. CA 